\title{
Risk Management Based on NPV-at-Risk: A Case Study in Floating Solar Power Plant Project
}

\author{
Octa Bimansyah Untoro *, Fakhrina Fahma, Wahyudi Sutopo \\ Department of Industrial Engineering, Universitas Sebelas Maret Surakarta, Indonesia \\ Jalan Ir. Sutami No.36A, Indonesia \\ * Corresponding author: oktauntoro@student.uns.ac.id
}

\section{ARTICLE INFO}

Article history

Received June 2, 2021

Revised August 16, 2021

Accepted August 21, 2021

Available Online August 31, 2021

Keywords

Risk Management

Floating Solar Power Plant

Mitigation

NPV-at-risk

\begin{abstract}
There are some unpredicted factors in floating solar power plants that can affect the investment return value. This research aimed to develop an NPV-at-risk based risk management analysis on the floating solar power plant. This research proposed six-staged solutions: communication and consultation, context assignment, risk identification, risk analysis, risk evaluation, and risk mitigation. This study took place in a floating solar power plant in Indonesia. This research showed that some unpredicted risks, such as irradiation, operation and maintenance costs, inflation, and interest rate, could contribute to the investment return. This procedural proposal could be applied in the management of the income realization based on the income projection.
\end{abstract}

This is an open-access article under the CC-BY-SA license.

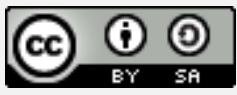

\section{Introduction}

Some unpredictable factors need to be considered in operating a floating solar power plant $[1,2]$. Such unpredictability can manifest into risks for the developer and investors and require investigations $[3,4]$. One of the main risks is the annual energy production value, referred to as irradiation $[5,6]$. This risk arises due to the uncertainty of the amount of solar radiation due to weather factors. In addition, sun radiation affects the total electricity generated and affects the company's income [7, 8]. Another risk to consider is the failure of the Floating Photovoltaic (FPV) system, which affects the operation and maintenance costs [9-11]. Hence, a management risk investigation is needed to systematically and effectively manage and mitigate these risks [12-14].

Investors demand some assurance in the investment return value [15]. The investors need to see that the proposed income value can be converted into a realistic income value. Therefore, a systematical financial viability evaluation is required to reduce the income deviation [16-18]. One of the procedures that can be implemented to mitigate the unpredicted factors in realizing income is NPV-at-Risk [19, 20]. This method employed the principles of Monte Carlo simulation by considering the distribution of probabilities of each risk [21, 22].

Previous research has proposed several methods to manage risks. Among these methods, the most notable is the integration of the Doublely technique for order of preference by similarity to ideal solution and process failure mode effect analysis [23], the

https://doi.org/10.22219/JTIUMM.Vol22.No2.245-254 hww http://ejournal.umm.ac.id/index.php/industri ti.jurnal@umm.ac.id 
integration of failure modes and effects analysis, and the proactive maintenance strategies [24], and the fuzzy comprehensive evaluation with artificial neural network [25]. Other methods include surveys and risk significance index [26], cross-case analysis [27], GISbased multi-criteria decision analysis [28], and analytical hierarchy process [29]. Research by Albana and Saputra [30] integrated risk management and NPV-at-Risk. Unfortunately, this research did not result in a higher risk level after implementing the proposed mitigation solutions.

Reflecting on the previous research, studies employing NPV-at-Risk into risk management analysis in power plants are hardly found. As far as this research is concerned, no research has focused on the risk level evaluation in a floating solar power plant. A risk management analysis that cannot estimate risk level results in undetermined income realization. The mitigations conducted by previous research only proposed the strategies to overcome risks. However, the mitigations did not measure the risk level when the mitigation was implemented. Therefore, this research aimed to develop an integration of risk management and NPV-at-Risk to mitigate the operational risks of a floating solar power plant. Thus, this research aimed to contribute to the development of risk management in power plant projects.

\section{Methods}

\subsection{Proposed Risk Management Method}

This study proposed six-staged risk management in a power plant project, as illustrated in Fig. 1. The stages involve communication and consultation, context assignment, risk identification, risk analysis, risk evaluation, and risk mitigation. The detailed illustration for the stages is as follows.

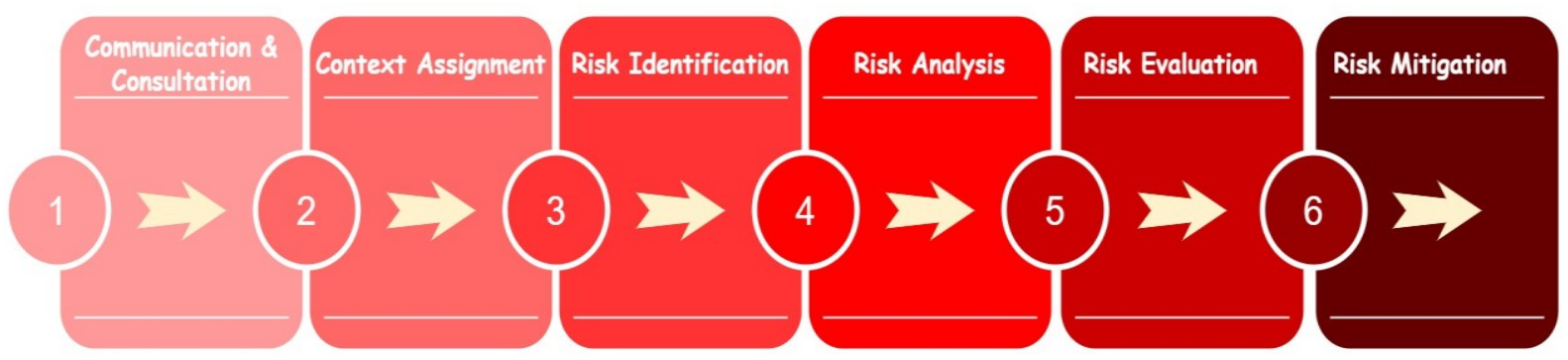

Fig. 1. Six Stages of Risk Management and NPV-at-Risk

At the initial stage, communication and consultation served to communicate the perception and understanding of parties bearing the risks. The discussion involved representations from the company handling the floating solar power plant project in Indonesia.

The second stage concerns context assignment. The assignment of context was presented in this stage. The risks' context was determined by the minimum Net Present Value (NPV) in this research. The minimum NPV helped in classifying the operational risks. The value was determined from the financial simulation, which was calculated based on the deviation between the cash in-flow in the future and cash out-flow in the present. The value of cash flow in a certain period was based on the interest rates and initial investment. Because the value of money in the present time is different from that in the future, the discount rate was also considered in this research. 
The value of the discount rate was obtained from the cost of equity. This value became the return value margin allowable in the project. The cost of equity (KE) was calculated based on equation (1). Based on the equation, the risk-free rate is denoted by $\mathrm{Rf}$, the sensitivity value of the return on the loan investment to the market return is $\beta$, and the market rate of return is $R m$.

$K E=R f+\beta(R m-R f)$

The calculation of NPV was based on equation (2). The minimum margin of NPV was obtained from calculating cash flow in the initial year (C1), second-year (C2), until the final year. Then, the values were obtained from the total net profit, which considered depreciation and amortization, interest rate, the discount value from the cost of equity, and initial investment (CO). Finally, the margin of NPV was used to estimate the likelihood level and the consequences of each risk.

$\mathrm{NPV}=\left(\mathrm{C} 1 /(1+\mathrm{r})^{1}\right)+\left(\mathrm{C} 2 /(1+\mathrm{r})^{2}\right)+\ldots+\left(\mathrm{Ct} /(1+\mathrm{r})^{\mathrm{t}}\right)-\mathrm{C} 0$

The third stage was the risk identification stage. This stage was reflected in the evaluation of the floating solar power plant operation. The steps in identifying risks included identifying and describing the risks that support and hinder the organization's objectives. In this stage, an expert discussed and answered interview questions to obtain data on each risk factor affecting the company's income.

The next stage was risk analysis. Initially, the measurement of risk determined the type of probability distributions for each risk factor. The selection of distribution type was used to conduct the Monte Carlo simulation. The next step was measuring the probabilities and consequences of each risk factor. The measuring of the probabilities was conducted based on the minimum NPV in the context assignment stage. The goal-seek method was implemented to determine the minimum value of each risk. The value of the possibility of occurrence for each factor was measured based on Monte Carlo simulation. The procedures of Monte Carlo simulation were as follows: (1) determining the type of risk factor data distribution, (2) determining the random order of the risk, (3) conducting random variable generation, and (4) conducting risk simulation.

The measurement of consequence was conducted based on financial loss. The value of the financial loss was used to measure the risk level obtained from the Monte Carlo simulation. The evaluation was measured in percentage obtained from the deviation of the initially targeted NPV and the final NPV based on the risk factor value. The highest risk factor value was selected to measure the worst probability of the risk. The classification of the level of possibility of occurrences and consequences of each risk factor is shown in Table 1 and Table 2, respectively. The results were used to construct risk mapping. The mapping helped determine the priorities in risk mitigation. The risk mapping from the level of possibility of occurrences and consequences is shown in Fig. 2.

Table 1. Likelihood Level

\begin{tabular}{ll}
\hline Likelihood & Possibility of Occurrence \\
\hline Rare & Possibility of occurrence less than $5 \%$ \\
\hline Unlikely & Possibility of occurrence between $5 \%-25 \%$ \\
\hline Possible & Possibility of occurrence between $25 \%-50 \%$ \\
\hline Likely & Possibility of occurrence between $50 \%-75 \%$ \\
\hline Almost Certain & Possibility of occurrence more than $5 \%$
\end{tabular}


Table 2. Consequences Level

\begin{tabular}{ll}
\hline Consequence & Description \\
\hline Insignificant & Low financial loss (indicates by correlation in absolute less than $5 \%$ ) \\
\hline Minor & Medium financial loss (indicates by correlation in absolute between $5 \%-25 \%$ ) \\
\hline Moderate & High financial loss (indicates by correlation in absolute between $25 \%-50 \%$ ) \\
\hline Major & Major financial loss (indicates by correlation in absolute between $50 \%-75 \%)$ \\
\hline Catastrophic & Huge financial loss (indicates by correlation in absolute more than $75 \%$ ) \\
\hline
\end{tabular}

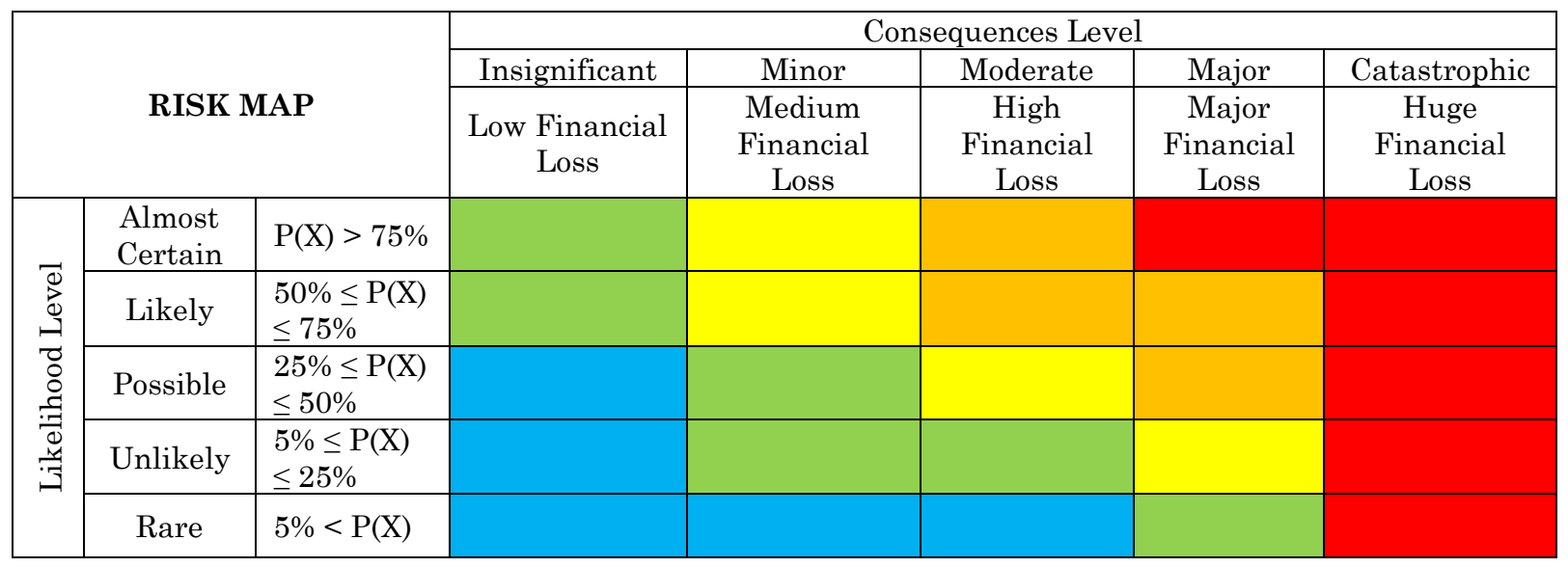

\begin{tabular}{|c|c|c|c|c|c|}
\hline Note & $\begin{array}{c}\text { Extreme } \\
\text { Risk }\end{array}$ & High Risk & $\begin{array}{c}\text { Moderate } \\
\text { Risk }\end{array}$ & Low Risk & $\begin{array}{c}\text { Extreme } \\
\text { Low Risk }\end{array}$ \\
\hline
\end{tabular}

Fig. 2. Risk Mapping

The fifth stage was risk evaluation. In this stage, risk evaluation was conducted to determine the critical risk factor. The level of the risk indicated this factor. Thus, the critical risk factor was derived from the levels of risk, which were notated as extreme risk, high risk, and moderate risk. Meanwhile, the low and extremely low risks were not classified as the critical risk factors.

The final stage was risk mitigation. In this stage, risk mitigation was proposed to prevent risks. The risk mitigation was conducted by designing a strategy to overcome the critical risk factors. Furthermore, classification of risk level was also conducted on the effects of mitigations proposed.

\subsection{Data Collection}

This research presented a study case on the floating solar power plant in Indonesia. There were primary and secondary data in this research. At the risk identification stage, the data were obtained from interviews and discussions with an expert. Furthermore, the secondary data were collected from the context assignment and risk-analysis stages. The data were used to determine the minimum margin of NPV and the type of risk probability distributions (see Table 3). The data collected from the context assignment were risk-free rate (Rf) at $6,45 \%$, beta (B) at 0.88 , and market rate of return $(\mathrm{Rm})$ at $9,78 \%$. In addition, data on the risks, including interest rate, inflation, operation and maintenance costs, and irradiation, were collected from the risk history within ten years of operation (2011-2020). 
Table 3. Types of Distribution of Risk Factors

\begin{tabular}{lll}
\hline No & Parameter & Distribution Type \\
\hline 1 & O\&M Cost & Lognormal $(-4.221 ; 0.2821 ; 0)$ \\
\hline 2 & Iradiasi & Lognormal $(12.45 ; 0.05644 ; 0)$ \\
\hline 3 & Interest rate & Lognormal $(-3.211 ; 0.1834 ; 0)$ \\
\hline 4 & Inflation & Normal $(0.04503 ; 0.01683)$ \\
\hline
\end{tabular}

\section{Results and Discussion}

This section presents the results from the analysis of NPV-at-Risk based risk management. The communication and consultation stage results indicate that this particular floating solar power plant will operate until the next twenty-five years. The investors entrust the developer of the power plan to manage the income realization according to the plan. The results from the context assignment show that the cash flows in the initial year $(\mathrm{C} 1)$, second-year $(\mathrm{C} 2)$, and the $25^{\text {th }}$ year $(\mathrm{C} 25)$ are $\$ 11,758,220, \$$ $10,702,200$, and $\$ 998,110$, respectively. The cost of equity (CE) obtained from the research is $9.38 \%$. The minimum margin of the NPV is $\$ 74,539,280$.

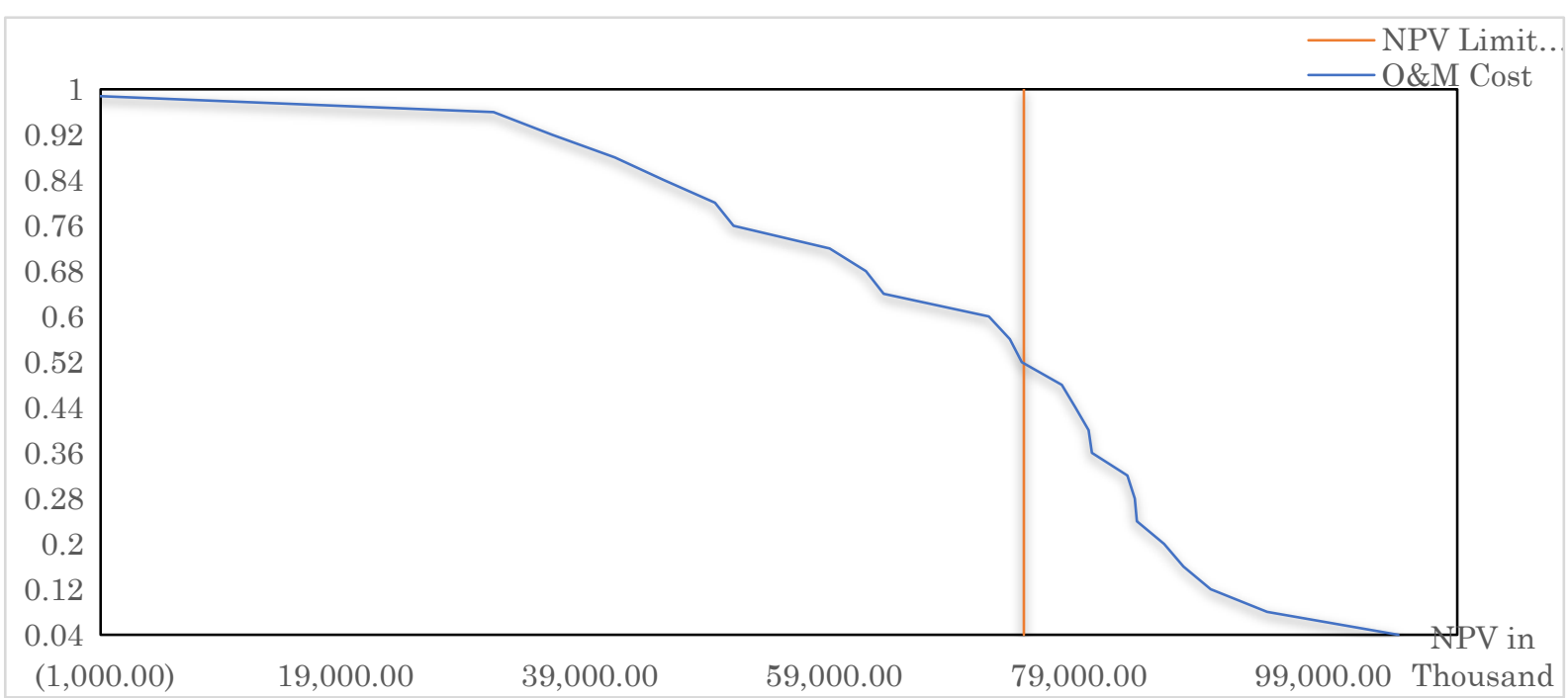

Fig. 3. O\&M Cost Probability Graph

The results of the Monte Carlo simulation suggest that the possibility of occurrence of the maintenance and operation costs exceeded the minimum margin of NPV at $48 \%$, as illustrated in Fig. 3. The complete description of the possibility of occurrence of the risk factors is presented in Table 4. In the maintenance and operation costs, the lost financial value was $11.5 \%$. It shows that the consequence level of the maintenance and operation costs is catastrophic. Further elaborations on the consequence results from each risk factor are presented in Table 5.

In detail, the mapping of risk factors is illustrated in Fig. 4. The research results suggest that two risk factors (inflation and maintenance and operation costs) reached an extreme risk level. Meanwhile, two other risk factors (irradiation and interest rate) were categorized as extremely low risks. 
Table 4. Likelihood factors risk results

\begin{tabular}{cccc}
\hline Risk & Parameter & Possibility & Level Likelihood \\
\hline & O\&M Cost $\geq 0.0196$ & $48.0 \%$ & Almost Certain \\
\cline { 2 - 4 } NPV $\leq \$ 74,539,280$ & Iradiasi $\leq 206,965$ & $0.0 \%$ & Rare \\
\cline { 2 - 4 } & Interest Rate $\geq 9.69 \%$ & $0.0 \%$ & Rare \\
\cline { 2 - 4 } & Inflation $\geq 4.06 \%$ & $84.0 \%$ & Almost Certain
\end{tabular}

Table 5. Consequences Results from each factors risk

\begin{tabular}{cccc}
\hline Risk & Parameter & Loss & Level \\
\hline & O\&M Cost $\geq 0.0196$ & $-115.0 \%$ & Catastrophic \\
\cline { 2 - 4 } $\mathrm{NPV} \leq \$ 74,539,280$ & Iradiasi $\leq 206,965$ & $-22.0 \%$ & Minor \\
\cline { 2 - 4 } & Interest Rate $\geq 9.69 \%$ & $-4.0 \%$ & Insignificant \\
\cline { 2 - 4 } & Inflation $\geq 4.06 \%$ & $-175.0 \%$ & Catastrophic
\end{tabular}

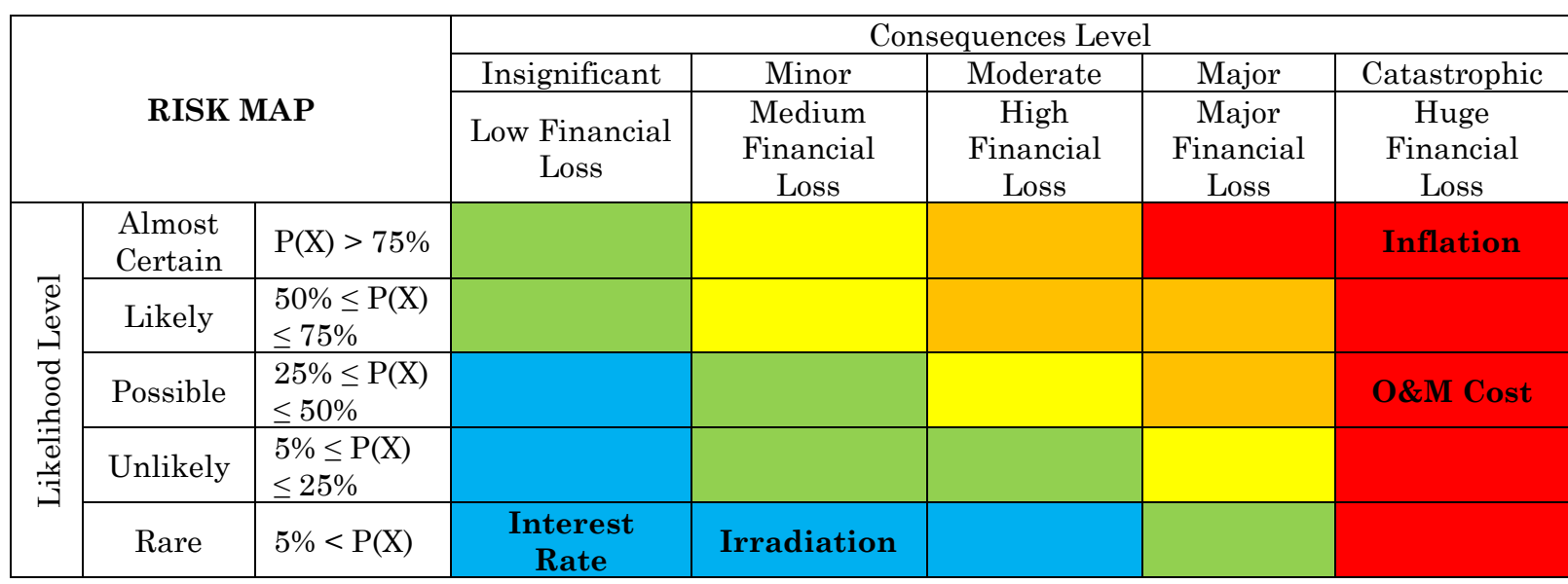

\begin{tabular}{|c|c|c|c|c|c|}
\hline Note & $\begin{array}{c}\text { Extreme } \\
\text { Risk }\end{array}$ & High Risk & $\begin{array}{c}\text { Moderate } \\
\text { Risk }\end{array}$ & Low Risk & $\begin{array}{c}\text { Extreme } \\
\text { Low Risk }\end{array}$ \\
\hline
\end{tabular}

Fig. 4. The mapping of each risk factor

According to the mapping of risks, several mitigation solutions are offered. The mitigation strategy on the inflation risk is modifying the unpredictability of the inflation rate, which affects the operational costs. As a result, the developer eliminates inflation risk because customers pay for the risk. This way, inflation is categorized into low risk. The mitigation for maintenance and operation costs requires the developer to determine the limit for maintenance and operation costs at $\$ 1,225.000$ per semester or $\$ 0,01469$ per watt peak per annum. With this strategy, the developer can reduce the costs by $115 \%$ and boost profit by $25 \%$.

The solution is to reduce maintenance and operation costs to mitigate irradiation risk to reach the realization value close to the initial investment value. The developer is suggested to reduce maintenance and operation costs by $\$ 715.000$ per semester or $\$ 0.00858$ per watt peak per annum. This strategy results in a decrease of profit loss from $22 \%$ to become $16 \%$. Furthermore, hedging is the proposed strategy to mitigate the risk of 
interest rate. Hedging is performed by determining the value of the interest rate at a certain percentage by the investor or the bank. The proposed interest rate scheme is to lock at $4.61 \%$. This way, the risk factor becomes lower because the income realization value is similar to the initially targeted income value. Furthermore, the results of the proposed mitigations are mapped in the risk mapping in Fig. 5. Reflecting on the map, the priorities for mitigation such as maintenance and operation costs and inflation show decreases of risk level, indicating that the mitigation strategies successfully reduced the risks.

\begin{tabular}{|c|c|c|c|c|c|c|c|}
\hline \multirow{3}{*}{\multicolumn{3}{|c|}{ RISK MAP }} & \multicolumn{5}{|c|}{ Consequences Level } \\
\hline & & & Insignificant & \multirow{2}{*}{$\begin{array}{c}\text { Minor } \\
\text { Medium } \\
\text { Financial } \\
\text { Loss }\end{array}$} & \multirow{2}{*}{$\begin{array}{c}\text { Moderate } \\
\text { High } \\
\text { Financial } \\
\text { Loss }\end{array}$} & \multirow{2}{*}{$\begin{array}{c}\text { Major } \\
\text { Major } \\
\text { Financial } \\
\text { Loss }\end{array}$} & \multirow{2}{*}{$\begin{array}{c}\text { Catastrophic } \\
\text { Huge } \\
\text { Financial } \\
\text { Loss }\end{array}$} \\
\hline & & & $\begin{array}{l}\text { Low Financial } \\
\text { Loss }\end{array}$ & & & & \\
\hline \multirow{5}{*}{ 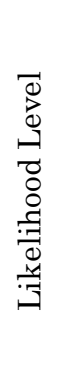 } & $\begin{array}{l}\text { Almost } \\
\text { Certain }\end{array}$ & $\mathrm{P}(\mathrm{X})>75 \%$ & & & & & Inflation \\
\hline & Likely & $\begin{array}{l}50 \% \leq \mathrm{P}(\mathrm{X}) \\
\leq 75 \%\end{array}$ & & & & & \\
\hline & Possible & $\begin{array}{l}25 \% \leq \mathrm{P}(\mathrm{X}) \\
\leq 50 \%\end{array}$ & & & & & O\&M Cost \\
\hline & Unlikely & $\begin{array}{l}5 \% \leq \mathrm{P}(\mathrm{X}) \\
\leq 25 \%\end{array}$ & & & & & \\
\hline & Rare & $5 \%<\mathrm{P}(\mathrm{X})$ & $\begin{array}{c}\text { Interest } \\
\text { Rate }\end{array}$ & Irradiation & & & \\
\hline
\end{tabular}

\begin{tabular}{|c|c|c|c|c|c|}
\hline Note & $\begin{array}{c}\text { Extreme } \\
\text { Risk }\end{array}$ & High Risk & $\begin{array}{c}\text { Moderate } \\
\text { Risk }\end{array}$ & Low Risk & $\begin{array}{c}\text { Extreme } \\
\text { Low Risk }\end{array}$ \\
\hline
\end{tabular}

Fig. 5. Risk Mapping based on Mitigation

\section{Conclusion}

This research aimed to manage risk factors by employing NPV-at-Risk in a floating solar power plant project. The four risk factors identified are irradiation, maintenance and operation costs, inflation, and interest rate. The results show that inflation and maintenance and operation costs were considered extreme risks. Therefore, the research proposed mitigation strategies to reduce the risk level of inflation and maintenance and operation costs to become extremely low risk and low risk. However, this research has a limitation in the analysis because each factor was analyzed partially. Additionally, the research did not analyze the possibility of combined risks. Therefore, future research needs to analyze the level of risks obtained from combinations of risks.

\section{Data Availability}

All data generated or analyzed during this study are included in this article.

\section{Declarations}

Author contribution: The first author performed data collection and processing, as well as compiling article scripts. While the second and author writers assisted in the preparation of the article script.

Funding statement: This research does not require funding. 
Conflict of interest: This study is needed by Company $\mathrm{X}$ to convince or guarantee the investors of the mitigation for the unpredictable risks. It is expected that the findings can help the development of Floating Solar Power Plant in Indonesia.

Additional information: Risk factor data is not displayed because it is already represented with the type of data distribution of each risk.

\section{Acknowledgment}

We thank the anonymous reviewers for their careful reading of our paper and their many insightful comments and suggestions.

\section{References}

[1] A. P. Sukarso and K. N. Kim, "Cooling effect on the floating solar PV: Performance and economic analysis on the case of west Java province in Indonesia," Energies, vol. 13, no. 9, p. 2126, 2020. https://doi.org/10.3390/en13092126.

[2] L. Liu et al., "Prediction of short-term PV power output and uncertainty analysis," Applied Energy, vol. 228, pp. 700-711, 2018. https://doi.org/10.1016/j.apenergy.2018.06.112.

[3] J. Hu, R. Harmsen, W. Crijns-Graus, and E. Worrell, "Barriers to investment in utility-scale variable renewable electricity (VRE) generation projects," Renewable Energy, vol. 121, pp. 730-744, 2018. https://doi.org/10.1016/j.renene.2018.01.092.

[4] T. Compernolle, K. Welkenhuysen, E. Petitclerc, D. Maes, and K. Piessens, "The impact of policy measures on profitability and risk in geothermal energy investments," Energy Economics, vol. 84, p. 104524, 2019. https://doi.org/10.1016/j.eneco.2019.104524.

[5] I. Jamil, J. Zhao, L. Zhang, S. F. Rafique, and R. Jamil, "Uncertainty Analysis of Energy Production for a $3 \times 50 \mathrm{MW}$ AC Photovoltaic Project Based on Solar Resources," International Journal of Photoenergy, vol. 2019, p. 1056735, 2019. http://doi.org/10.1155/2019/1056735.

[6] W. Jeon and C.-Y. Lee, "Estimating the Cost of Solar Generation Uncertainty and the Impact of Collocated Energy Storage: The Case of Korea," Sustainability, vol. 11, no. 5, 2019. http://doi.org/10.3390/su11051389.

[7] M. Wieczorek-Kosmala, "Weather Risk Management in Energy Sector: The Polish Case," Energies, vol. 13, no. 4, 2020. http://doi.org/10.3390/en13040945.

[8] K. Halsnæs, L. Bay, P. S. Kaspersen, M. Drews, and M. A. Larsen, "Climate Services for Renewable Energy in the Nordic Electricity Market," Climate, vol. 9, no. 3, 2021. http://doi.org/10.3390/cli9030046.

[9] J. A. B. Wirawan and I. Garniwa, "Risk Analysis Development of Solar Floating Power Plant in The Sea with Monte Carlo Method," in 2018 3rd International Conference on Information Technology, Information System and Electrical Engineering (ICITISEE), 2018, pp. 396-401.

[10] A. Sen, A. S. Mohankar, A. Khamaj, and S. Karmakar, "Emerging OSH Issues in Installation and Maintenance of Floating Solar Photovoltaic Projects and Their Link with Sustainable Development Goals," Risk management and healthcare policy, vol. 14, pp. 1939-1957, 2021. http://doi.org/10.2147/RMHP.S304732.

[11] S. Oliveira-Pinto and J. Stokkermans, "Marine floating solar plants: an overview of potential, challenges and feasibility," vol. 173, no. 4, pp. 120-135, 2020. http://doi.org/10.1680/jmaen.2020.10. 
[12] B. Pieket Weeserik and M. Spruit, "Improving Operational Risk Management Using Business Performance Management Technologies," Sustainability, vol. 10, no. 3, 2018. http://doi.org/10.3390/su10030640.

[13] A. Aloqab, F. Alobaidi, and B. J. B. Raweh, "Operational risk management in financial institutions: An overview," Business economic research, vol. 8, no. 2, pp. 10$32,2018$.

[14] G. H. Silva Rampini, H. Takia, and F. T. Berssaneti, "Critical Success Factors of Risk Management with the Advent of ISO 310002018 - Descriptive and Content Analyzes," Procedia Manufacturing, vol. 39, pp. 894-903, 2019. https://doi.org/10.1016/j.promfg.2020.01.400.

[15] K. G. Firouzjah, "Assessment of small-scale solar PV systems in Iran: Regions priority, potentials and financial feasibility," Renewable and Sustainable Energy Reviews, vol. 94, pp. 267-274, 2018. https://doi.org/10.1016/j.rser.2018.06.002.

[16] J. Liu, F. Jin, Q. Xie, and M. Skitmore, "Improving risk assessment in financial feasibility of international engineering projects: A risk driver perspective," International Journal of Project Management, vol. 35, no. 2, pp. 204-211, 2017. https://doi.org/10.1016/j.ijproman.2016.11.004.

[17] T. Adefarati and R. C. Bansal, "Reliability, economic and environmental analysis of a microgrid system in the presence of renewable energy resources," Applied Energy, vol. 236, pp. 1089-1114, 2019. https://doi.org/10.1016/j.apenergy.2018.12.050.

[18] J. Janekova, J. Fabianova, and J. Kadarova, "Selection Of Optimal Investment Variant Based On Monte Carlo Simulations," International Journal of Simulation Modelling, vol. 20, no. 2, pp. 279-290, 2021. https://doi.org/10.2507/IJSIMM20-2-557.

[19] A. Jahani, P. Mohammadi, and H. Mashreghi, "Studying Risk Effect in Evaluating the Financing Methods of New Technology-Based Firms," IUST, vol. 29, no. 2, pp. 133-146, 2018. http://doi.org/10.22068/ijiepr.29.2.133.

[20] Y. Kim and E.-B. Lee, "A Probabilistic Alternative Approach to Optimal Project Profitability Based on the Value-at-Risk," Sustainability, vol. 10, no. 3, pp. 747, 2018. http://doi.org/10.3390/su10030747.

[21] P. B. Gilbile and G. S. Vyas, "Financial Risk Identification and Management of Road Projects in Hybrid Annuity Model," in International Conference on Transportation and Development 2021, 2021, pp. 101-109.

[22] L. Kumar, A. Jindal, and N. R. Velaga, "Financial risk assessment and modelling of PPP based Indian highway infrastructure projects," Transport Policy, vol. 62, pp. 211, 2018. https://doi.org/10.1016/j.tranpol.2017.03.010.

[23] I. Das, D. Panchal, and M. Tyagi, "A novel PFMEA-Doubly TOPSIS approach-based decision support system for risk analysis in milk process industry," International Journal of Quality \& Reliability Management, vol. ahead-of-print, no. ahead-of-print, 2021. http://doi.org/10.1108/IJQRM-10-2019-0320.

[24] J. Rukijkanpanich and M. Mingmongkol, "Enhancing performance of maintenance in solar power plant," Journal of Quality in Maintenance Engineering, vol. 26, no. 4, pp. 575-591, 2020. http://doi.org/10.1108/JQME-11-2018-0098.

[25] L. Bai, Z. Wang, H. Wang, N. Huang, and H. Shi, "Prediction of multiproject resource conflict risk via an artificial neural network," Engineering, Construction and Architectural Management, vol. ahead-of-print, no. ahead-of-print, 2020. http://doi.org/10.1108/ECAM-03-2020-0201.

[26] M. N. Addy, S. Akunyumu, and B. Simons, "Key risk factors affecting renewable energy independent power producer (IPP) set-up projects in developing countries," Journal of Engineering, Design and Technology, vol. 17, no. 6, pp. 1340-1355, 2019. http://doi.org/10.1108/JEDT-03-2019-0072. 
[27] C. Ameyaw and H. W. Alfen, "Identifying risks and mitigation strategies in private sector participation (PSP) in power generation projects in Ghana," Journal of Facilities Management, vol. 15, no. 2, pp. 153-169, 2017. http://doi.org/10.1108/JFM07-2016-0030.

[28] S. N. Shorabeh, M. K. Firozjaei, O. Nematollahi, H. K. Firozjaei, and M. JelokhaniNiaraki, "A risk-based multi-criteria spatial decision analysis for solar power plant site selection in different climates: A case study in Iran," Renewable Energy, vol. 143, pp. 958-973, 2019. https://doi.org/10.1016/j.renene.2019.05.063.

[29] N. T. Suprova, M. A. R. Zidan, and A. H. Rashid, "Optimal Site Selection for Solar Farms Using GIS and AHP: A Literature Review," vol. 149, pp. 565-576, 2020.

[30] A. S. Albana and Y. A. Saputra, "Financial Risk Assessment For Power Plant Investment Under Uncertainty Using Monte Carlo Simulation," in 2019 International Conference on Technologies and Policies in Electric Power \& Energy, 2019, pp. 1-6. 